\title{
Emotional and social representations of future teachers about sexually transmitted diseases
}

\author{
Carmen María Aránzazu Cejudo Cortés ${ }^{1 \mathrm{a}}$, and Celia Corchuelo Fernández ${ }^{1 \mathrm{a}}$ \\ ${ }^{1}$ University of Huelva, Faculty of Educational Sciences, Campus el Carmen, Avenida 3 de marzo s/n, \\ 21071 Huelva,Spain
}

\begin{abstract}
Health Education programs for young people have drastically increased in recent years in Spanish universities. In part, this is due to the fact that new cases of infection of a sexually transmitted disease continue happening, especially at this stage, and universities as an educational space in which a large number of young people are concentrated, must address this problem. Training young students in promoting healthy sexual habits will prevent not only new infections, but also facilitate the acquisition of competences in the students of the health and socio-educational areas, necessary for their later professional development. This research provides some information about the knowledge and attitudes of students of educational qualifications about HIV/AIDS, with particular relevance to the emotions and social representations that the students have about this fact and that can interfere in their lack of information making them more vulnerable to the disease.
\end{abstract}

Keywords: Diseases, sexual habits, young students.

\section{Introduction}

Despite the obvious progress made in scientific research, antiretroviral therapy and dissemination of information on HIV/AIDS, there is still a long way to go, especially in preventing new infections and the consequent need to maintain and strengthen Social and educational actions. Over the world, but particularly in countries with more economic resources, access to pharmacological treatment has led to a dramatic decline in AIDS mortality [1]. However, even in these countries, there are still problems to control this pandemic, with worrying data such as the stability of the number of new cases per year, mostly in young people, and the late diagnosis in many of them [2].

At present, the young population is the world's most vulnerable due to risky sexual practices, which is the main route of contagion. In addition, a great number of infected people are unaware of their serological status, which favors the progression of infection and

\footnotetext{
${ }^{a}$ Corresponding author: carmen.cejudo@dedu.uhu.es; celia.corchuelo@dedu.uhu.es
} 
the spread of the virus [3-5]. For all these reasons, they insist on the need to promote and develop socio-educational prevention and intervention policies.

Multisectoral plan against HIV infection and AIDS in Spain [6] points out that for years our country has maintained infection rates above the EU average, despite efforts to prevent new infections. This report indicates that there are between 120,000 and 150,000 Spanish citizens infected with HIV and that more than a quarter of them are unaware that they are. And that each year there are between 2,500 and 3,500 new diagnoses that mainly affect young people. This fact, that is to say, the vulnerability of young people to HIV, basically due to their risky sexual practices, led us to ask ourselves about the level of knowledge and the type of attitudes they have in relation to this disease, as a starting point to support effective socio-educational intervention. This intervention can only be implemented with conscious and well-educated educators in relation to this problem. Do our current students have, I mean, those who will become teachers the perception of having that training? What are your attitudes towards HIV/AIDS?

The Teaching Innovation Project titled "Mejora de la acción tutorial individual y grupal en programas de educación para la salud y prevención del VIH/SIDA" of the University of Huelva and whose main investigators are the authors of this article, aims to address not only the attitudes, but also the knowledge and representations of this student population. Our study, as will be seen below, tries to find out by means of a thoroughly elaborated questionnaire, which was applied to a sample of more than six hundred subjects, as well as several groups of discussion and analysis of documents elaborated by the subjects of the sample.

\section{The promotion of health in Spanish universities}

The importance given to the promotion of healthy habits as a form of prevention of diseases and addictions has been progressively increased over recent years, finding one of its ideal frameworks in universities [7]. The main reasons for this formation are due to the fact that higher education institutions are the places where future professionals are prepared, who will play a relevant role in the public life of the country to which they belong and spend much of their time there during their student years. For this reason, the university is undoubtedly the site as well as the temporary space of life adequate to transmit good health practices, which will be consolidated in later years, impacting on the immediate environment, taking into account, the future impact that can have this training when dealing with students who in the near future will be education professionals $[8,9]$.

It is also significant to choose precisely this stage of life of the individual for the intensive promotion of healthy habits, because that is when at greater risk is exposed in terms of sexuality and drug abuse. However, the intention of those who promote preventive and awareness-raising actions is that the attitude adopted by them is perpetuated and has a positive impact on the workplace, on social and family relations, on integration into a community and even at the citizen level. Not surprisingly, the university student must combine his knowledge and academic skills with those referring to health, since they will have to put them, in the same way, in practice in their personal and work future [10]. In the research presented in this article, the subjects who participated in the study will be in the near future, teachers and educators who will have to give an effective response to situations that may occur in a given educational context.

To sum up and in a global view, the conjunction of the objectives, the strategic lines and action, and the philosophy of the Universities Promoting Health, is described as much both as by the Spanish Network of Healthy Universities and by the research that supports the Movement and try to make improvements in it, and all of it is concluded the following: 
«A Health Promotion University is concerned with developing institutional regulations that generate a healthy culture within the walls of the university, while offering educational activities, literacy and communication in health and prevention and care services.. It also integrates professional academic training in Health Promotion and Health Education into its university education programs and fosters research and evaluation in these fields from. It also seeks partnerships with other health promotion centers at community, national and international levels. And lastly, he gives an example of the reconstruction of his own infrastructures in pursuit of healthy habits» [11].

\section{HIV I AIDS and social stigmatization}

Since the first cases of seropositive children were known within the school environment (the first documented discrimination in Spain occurred in 1987) it was observed how, as the spread of the disease progressed, discriminatory attitudes were produced in all the social contexts, being obvious that they would also be produced in the educational institutions.Unjustified discriminatory attitudes continue to be produced during these more than 30 years due to the fear that promotes the probability of transmission, motivated by lack of information in this regard. In the research we address, it has been intended to know, among other issues, what can those people who are planning to work in education, do to face the hard task of changing social preconceptions about AIDS/HIV and value if they are ready to face that challenge. The need to improve the fundamental pedagogical tools and resources to address these difficulties in our work as teachers justifies in large part the interest of this study.

This fear has been unfounded or based on irrational fears and social and cultural prejudices, to which these professionals, as active components of their own society and culture, cannot escape [12]. Therefore, the need to change social attitudes and behaviors towards HIV is ratified, a transformation that is inevitably due to the suppression of prejudices without a demonstrable basis and irrational fears [13].

The FIPSE study [14] that addresses the arbitrary discrimination of people living with HIV or AIDS, states that training must be focused on permanently eradicating attitudes of discrimination and stigmatization towards people with HIV/AIDS and, if effective, will result in a "radical change of attitudes". Moreover, teacher training in general, and not only that of subjects related to health and medicine, should contain educational programs that change the popular imaginary or archetypal about this fact.

It is easily deductible that stigma is one of the main sources of negative attitude towards HIV, making it a sine qua non condition for rejection and discriminatory behavior towards infected and at-risk groups. Already warned of the consequences of stigma, being an attribute that socially discredits the person who owns it, leaving the individual defenseless against reactions of rejection that, in turn, favor isolation and trigger feelings of guilt and self-rejection, which do no more that worsen the social situation of the affected [15].

There are countries, as in the case of Nicaragua, in which the struggle focuses on other, more localized, prejudices, for example, those caused by macho behavior towards sexual behavior. That is why it is confirmed that higher levels of studies have not yet succeeded in eradicating the indisputable male predominance in the decision making on sexual habits and prophylaxis [16]. This form of discrimination causes a woman to lose her right to take care of herself and to decide on her health, with her own partner coming to blame and stigmatizing her if, as a result of the described attitude, she contracts the virus.

The possibility of providing this information to the most affected population group in the developed countries, the young population, and the choice of socio-educational qualifications to train these students in skills that develop healthy habits in their future educational centers, will help prevent risky sexual relations from the beneficiary students 
and also to develop their competences as professionals of the education. Education must respond to the social needs that occur in our environment and, therefore, the students of the different educational qualifications should develop in the not too distant future, projects that improve the quality of life of their students, implementing programs health education at school and promoting healthy sexual practices.

\section{Methodological aspects and context of the research}

The research work presented in these pages has a general objective to know the attitudes of students of educational qualifications to HIV/AIDS, to offer diverse socio-educational responses if it proves necessary. This study was developed in the Faculty of Education Sciences of the University of Huelva. Of a total of 2,076 students enrolled in this faculty, a sample of 613 subjects was selected for the completion of the questionnaire. Taking into account that $79.8 \%$ of the students surveyed are less than or equal to 25 years of age, we are looking at a valuable sample for the purpose of this study, since not only do we try to know how future teachers, teachers/as well as educators face such a stigmatized disease, we also gain an important record of knowledge, perceptions and attitudes of one of the most affected groups by the HIV epidemic in developed countries, young people. The participants in the discussion group were 11 students and 89 people studying Social Education have drawn up graphic documents on attitudes towards HIV. Therefore, a total of 713 students have been consulted on the subject that is addressed in this research work.

\section{Results}

Both in the review of the scientific literature and in the field study itself, we find that the attitude of future education professionals is an extremely important element in the prevention of new HIV and stigma contagion. Some of the results obtained in this study, reveal the need to continue training university students in health education. Some of the opinions of the subjects of the sample are collected in the following lines as examples.

One of the commonly widespread myths is that HIV is transmitted through saliva. $36.7 \%$ of the subjects of the sample think that two babies cannot share their dummies when one of them is HIV positive as there is a high risk of contagion. In the discussion group, we also discussed this question and we observe the doubts presented in this case when two babies share dummies or pacifier:

"But it has been said that by saliva but children often have blood on their teeth, you will lose a tooth. That swapping a pacifier is like when you exchange a toothbrush with your partner or something that causes you to get blood. Then it is already contact by the blood...So I think we should tell the parents because somehow they have to put them in the alternative or take the necessary measures to be aware of those things" subject 4 the discussion group.

On the other hand, $25.6 \%$ of the students express that they would change their son or daughter from daycare if they knew that there are children with HIV/AIDS as we see in the following graph: 


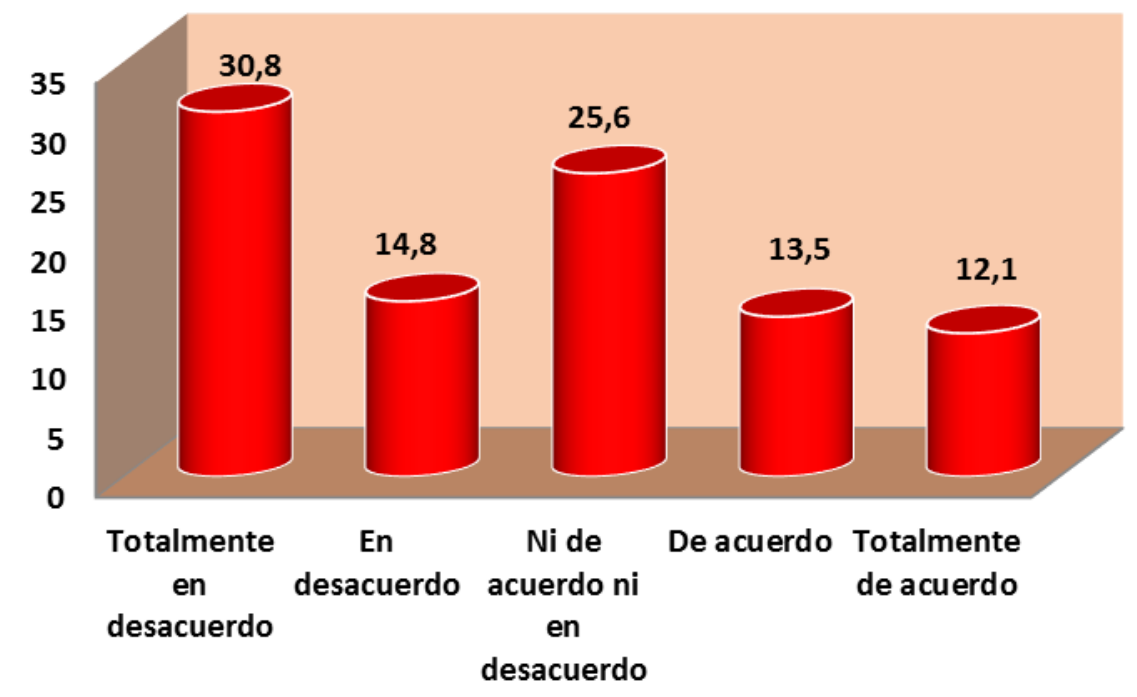

Fig. 1. Would you change your child's daycare if there were children with HIV/AIDS?

Another relevant fact is the one obtained when students were asked if they would "take strict hygienic measures if they were teachers in a class where there are people with HIV/AIDS." $39.8 \%$ agree with this question as shown in the following graph:

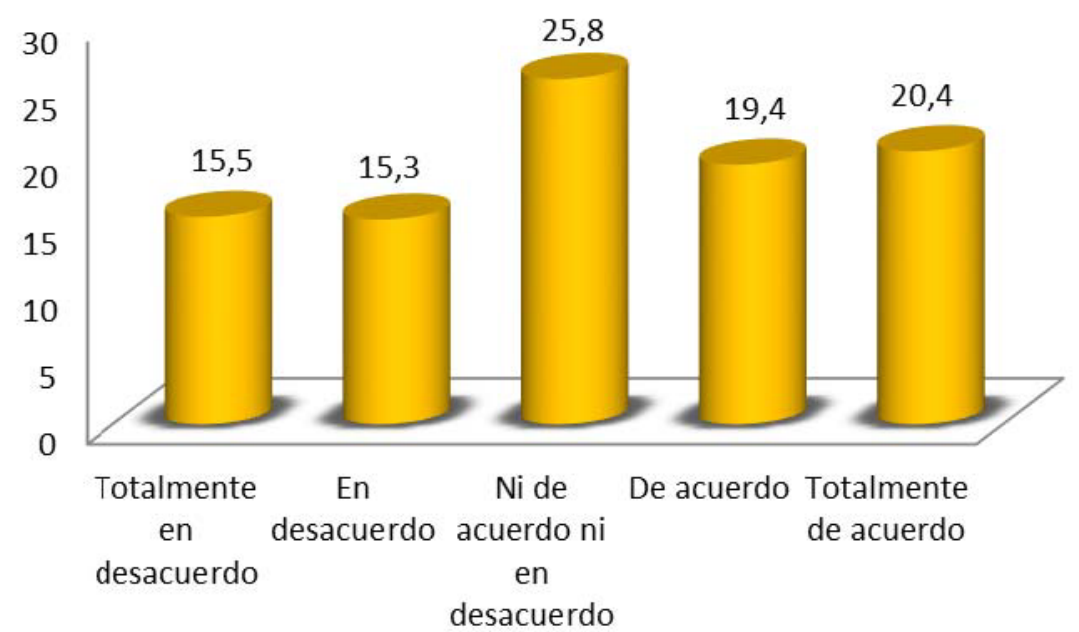

Fig. 2. Would you take strict hygienic measures if you were teaching in a class with HIV/AIDS people?

This fact encourages us to think that some of these strict hygienic measures carried out in a classroom could become discriminatory and possibly promote stigma. We already checked this fact in the questions that some of the subjects were asked when they participated in the discussion group, such as washing the clothes, or doubts about washing the dishes, cleaning the bathroom, etc. In the following lines we collect what the subjects of 
our discussion group thought if they should take special measures if there is an HIV positive child in a class:

"Do not intercalate in this case for example pacifiers, not take things to the mouth, be aware that if it falls, is that person who goes with adequate protection for that child "Subject 5 the discussion group.

"What protection?" Moderator

"For example gloves" Subject 5 the discussion group.

"That would be special treatment and we must treat all children equally." Subject 8 the discussion group.

"Anyway in the hospitals with these people it is not that they use gloves is that it uses double glove"Subject 2 the discussion group.

"That if they have a stepfather then they cannot be touched." Subject 9 the discussion group.

"This I do not know but take measures like the masks, in the sense that I might cough." Subject 6 the discussion group.

"I also think that a very important thing is also not taking too much care of us, we do not need to wear many gloves, face masks, because the other person ... is that they feel rejected. Subject 2 the discussion group.

$42.4 \%$ of the students that were asked have the opinion that if they were parents, they would have the right to know if there are children or teenagers infected in their child's class. These results suggest the following question: If the chances of transmitting the infection by sharing a classroom with a classmate are nil, what is the information needed for? Then, this would result in the fomentation of discriminatory attitudes of other students or parents which have not been properly informed that subsequently would affect the normal integration of the minors.

The discussion group also discusses this issue and, as you can see, there is a diversity of opinions about this fact:

"The truth is that I think that if I were the father of a child and there is a partner who has HIV to me I would like to know." Subject 8 the discussion group.

"But it is very difficult because if they had the others, of course we would want to know but not if they were our children. That person deserves a little privacy". Subject 9 the discussion group.

When the students were asked "if, in the case of they were teachers, they think that the parents of the children of their classes should know if there are children with HIV/AIDS", we find that $41.4 \%$ fully agree or agree on the issue that we have addressed thinking that if they are teachers in a class with HIV positive children, the parents of the rest of the students, would have the right to know. We want to re-emphasize that if the chances of transmitting the infection by sharing a classroom with a classmate are null, it is not necessary to give that information, besides that we would violate the confidentiality of the data of the student in question, being able to provoke discriminatory attitudes by other students or parents not properly informed that would affect the normal integration of these HIV positive students.

With regard to the emotions and social representations that generate the subjects of this research the words HIV or AIDS, some express the following:

"People with HIV are marked for life" subject 36 document analysis.

"People with HIV should feel sad because they feel like a bird locked in a cage, which cannot fly freely or do anything that might appeal to them. Time passes and is consumed while he is not totally happy or has no solution to his problem "subject the 52 document analysis.

"I think people would flee from me if I had HIV/AIDS" subject 59 document analysis. 
It can be seen how the social representations about HIV/AIDS (in almost half of the people that are part of this research) are still bound to a disease that provokes social rejection and isolation by the affected person. Disgrace, sadness, a truncated life evoked by death and loneliness, remains anchored in the representation of many people when referring to HIV.

Contrary to previous opinions, many of the students think that if they had HIV or AIDS, their daily lives would pass normally and they think they could do the same activities. Some examples of this are observed in the following narratives:

"Even if one has HIV, one can live in a positive way and lead a standardized life thanks to pharmacological treatment" subject 35 document analysis.

"But it would limit you, maybe, for example, when you have an accident and you stay in a wheelchair, you are really limited, but a person with HIV can lead a totally normal life" subject 3 .

"You can live a normal life, where love, opportunities, support, affection, family, friends, treatment, fun and travel have room for you" subject 45 document analysis.

\section{Conclusions}

The data obtained in our research confirm that there is a large percentage of university students who, despite having received training in school institutions and in the university itself, still do not know basic aspects of HIV/AIDS. Providing more comprehensive, concrete and repeated information over time at an early age can contribute to the prevention of new infections and, in addition, avoid discriminatory attitudes towards people living with HIV.

It is necessary to insist on the development of educational initiatives to prevent the stigma that people with HIV suffer and try to change the imaginary and pejorative social representations that provoke such attitudes. This will prevent people with HIV from continuing to feel vulnerable and undervalued in their rights. But this can only be achieved through training that helps to shake the foundations anchored in disinformation and ignorance. The aim is to establish and develop educational programs that train students (professional education professionals) to empathize with people with HIV/AIDS, to make them agents that not only avoid discriminatory actions but actively contribute to change of attitude in the educational field preventing new infections.

Likewise, the results of this research warn us that there are plots in which to continue deepening in the scientific field, and in the proposals for socio-educational interventions that contribute to overcome the prejudices and stigma associated with HIV, as well as establishing a more effective prevention with the most vulnerable group in our country, young people.

\section{References}

1. ONUSIDA. El SIDA en cifras. Ginebra: Programa Conjunto de las Naciones Unidas sobre el VIH/SIDA (2015)

2. Maquera-Afaray, J., Cvetkovic-Vega, A., Cárdenas, M. M., Kälviäinen, H., Mejia, C. R. Diagnóstico tardío y enfermedad avanzada de VIH en pacientes adultos en un hospital de la seguridad social de Perú. RevChilenaInfectol, 33, Supl 1, 20-26 (2016)

3. Rodríguez, M y Zamora C. Plan Andaluz frente al VIH/SIDA y otras ITS (2010-2015). Junta de Andalucía. Consejería de Salud (2010)

4. ONUSIDA. Informe de ONUSIDA para el día mundial del SIDA. Ginebra: Programa Conjunto de las Naciones Unidas sobre el VIH/SIDA (2016) 
5. FIPSE (Fundación para la Innovación y la Prospectiva en Salud en España). Retrieved fromhttps://fipse.es/ on 18.03.2017

6. Ministerio de Sanidad y Consumo. Plan multisectorial frente a la infección por VIH y el SIDA: España 2008-2012. (2008).

7. REUS (Red Española de Universidades Promotoras de Salud). Retrieved fromhttp://www.msssi.gob.es/profesionales/saludPublica/prevPromocion/promocion/U niversidadesSaludables/REUS.htm on 12.03.2017

8. REUS. Declaración de Pamplona/Iruña. IV Congreso de Universidades Promotoras de la Salud. (2009) Retrieved from

$\mathrm{http}: / / \mathrm{www}$. fundacion.unavarra.es/universidadsaludable/documentos/declaracion $\% 20 \mathrm{~d}$ e\%20pamplona.pdf on 18.03.2017

9. Arroyo, H. Desarrollo del Movimiento de Universidades Promotoras de la Salud. Centro Colaborador de la OMS-OPS para la Capacitación e Investigación en Promoción de la Salud y Educación para la Salud Escuela de Salud Pública, Universidad de Puerto Rico. (2012) Retrieved fromhttp://javeriana.edu.co/redcups/Hiram_Arroy_Movimiento_de_Universidades_Pro motoras_de_la_Salud.pdf on 20.03.17

10. González Alfaya, M. E. Intervención de la Universidad en la promoción de la salud de sus estudiantes. (U. S. Compostela, Ed.) Innovación Educativa, 19, 247-260 (2009)

11. Ministerio de Sanidad, Servicios Sociales e Igualdad. Gobierno de España. Universidades Saludables. (2013) Retrieved fromhttp://www.msssi.gob.es/profesionales/saludPublica/prevPromocion/promocion/U niversidadesSaludables/docs/AnexoI.pdf on 27.03.2017

12. Sábado J. T y Aradilla A. Actitud ante el sida en estudiantes de enfermería. ¿Cuál es el papel de la formación académica? Educación Médica, 6, 2, 87-92 (2003)

13. Dihigo, M. Actitudes ante el VIH-SIDA de los estudiantes que ingresan a la carrera de Medicina. Facultad de Ciencias Médicas. Matanzas. Curso, 2007 (2006)

14. FIPSE. Discriminación y VIH/SIDA. Estudio Fipse sobre discriminación arbitraria de las personas que viven con VIH o SIDA. Fundación para la Investigación y la Prevención del Sida en España (2005)

15. Goffman, E. Stigma: Notes on the Management of Spoiled Identity. Garden City, New York: Anchor Books (1963)

16. Sanchiz, D.C., Marchena, J.A.M., Jarquín, E.J.L., Costales, E.M.R.A propósito del SIDA: un estudio cualitativo sobre percepción y actitudes de estudiantes y profesorado universitario en Chontales, Nicaragua. Población y SaludenMesoamérica, 10, 2, 6-22 (2013) 